\title{
Border Crossings by Immigrants: Legality, Illegality, and Alegality
}

\author{
Hans Lindahl
}

Published online: 8 August 2008

(C) The Author(s) 2008. This article is published with open access at Springerlink.com

\begin{abstract}
What happens to the concept of security if legal disorder manifests itself not only as illegal behavior but also as alegal behavior-acts that challenge the very distinction between legality and illegality, as drawn by a political community? Focusing on European immigration policy, this paper examines how the distinction between illegal and alegal acts critically illuminates the relation between collective (in)security and the concept of legal (dis)order. It concludes by arguing that this distinction sheds new light on the systematic relation-and tension-between security, freedom, and justice.
\end{abstract}

Keywords Collective self-legislation · (Dis)order · Freedom · Immigration · Justice $\cdot$ Legality $\cdot$ Illegality $\cdot$ Alegality $\cdot$ Security

\section{Introduction}

What happens to the concept of security if legal disorder manifests itself not only as illegal behavior but also as alegal behavior-acts that challenge the very distinction between legality and illegality, as drawn by a political community? This question seems especially apposite with respect to immigration policy, as formulated in Europe's 'Area of Freedom, Security, and Justice' (AFSJ). On the one hand, the manifold technologies put in place under the aegis of the AFSJ, including passport controls, visas, electronic fences, registration, work permits, and the use of statistics and probability analysis for the establishment of risk profiles by the European Border Agency (Frontex), are increasingly justified in terms of the need to combat illegal immigration. On the other hand, there are good reasons to believe that immigration disrupts the European legal order not only because significant numbers

H. Lindahl (ه)

Department of Philosophy, Tilburg University, P.O. Box 90153, Tilburg, LE 5000, The Netherlands e-mail: H.K.Lindahl@uvt.nl 
of aliens sojourn illegally in the European polity, but also because their border crossings contest how this polity draws the distinction between legality and illegality. In fact, the ambiguity at the heart of immigration is not limited to security but spills over into the other two terms of the AFSJ, as well: what relation emerges between security, on the one hand, and freedom and justice, on the other, if one incorporates the distinction between illegal and alegal acts into the concept of legal disorder?

I will address these questions in six stages. The next section calls attention to what remains more or less implicit and taken for granted when security scholars attempt to define their object of study: the problem of (dis)order. Approaching political order from the perspective of collective self-legislation, the third section offers a thumbnail sketch of the corresponding concept of legal order and the four kinds of boundary it sets to human action. Turning to the problem of disorder, the fourth section introduces the basic distinction between illegal and alegal acts, and shows how this distinction pertains to border crossings by immigrants. Having perused both legal order and disorder, the paper moves on to consider collective insecurity and security. The fifth section focuses on collective insecurity, arguing that it is intimately linked to acts which challenge legal boundaries. The sixth section asserts that collective security is linked to the acts whereby authorities respond to those challenges by positing legal boundaries anew. In the same way that illegal and alegal acts are two different ways of challenging the boundaries of a legal order, boundary-enforcement and boundary-constitution are two distinct ways by which authorities claim to restore collective security. I will argue, however, that there is an irreducible indeterminacy concerning the nature of border crossings by immigrants, and how they should be responded to. The final section addresses a pressing question: why should a polity respond to border crossings by immigrants in a way that not only combats illegality but also redefines how the polity draws the distinction between inside and outside? An answer to this question brings into view the primordial relation between security, justice, and freedom: reducing alegal border crossings to illegal border crossings ultimately compromises the conditions under which boundary-enforcement can be deemed an act of collective self-legislation, that is, the free act of a collective that metes out to each their own.

\section{What is Security?}

European authorities appeal to freedom and justice when justifying the priority of security considerations in the design and implementation of immigration policy. Preventing and combating illegal immigration, they claim, promotes freedom, interpreted as the right of the members of the European polity to determine among themselves and in their own interest which aliens may be included and excluded from the European polity. Preventing and combating illegal immigration, they further claim, also promotes the cause of justice, interpreted as the acts by which the members of the European polity determine among themselves who is entitled to what, including the right to participate in the internal market. A number of scholars 
have taken strong issue with these claims. Decrying the exclusive interpretation of political community fostered by security-talk, these scholars argue that immigration must be 'desecuritized,' thereby facilitating an inclusive conception of political society in which freedom and justice can thrive. ${ }^{1}$ In short, whereas political authorities claim that freedom and justice are contingent on security, a variety of scholars critique security in the name of freedom and justice.

Considered this way, European immigration policy as it now stands raises a fundamental question: what is security, and how does it relate to freedom and justice? One would expect that security studies would have a ready answer to at least the first part of this question. Yet, as one contemporary scholar points out, security studies are in crisis as a result of an incapacity to establish the actual object of study. ${ }^{2}$ Whereas the concept of security remained more or less uncontroversial during the Cold War, its scope, locus, and orientation have thereafter become increasingly contentious. If the scope of security was initially confined to, roughly, military threats to the state's existence and its continued capacity to exercise sovereignty, issues such as environmental degradation and immigration are increasingly labeled as security problems. In an attempt to retain a certain differentiation in the field, security scholars have introduced new thematic divisions, such as the distinction between 'state' and 'societal' security, only to discover that these distinctions immediately become the object of intense and protracted debate. Also the locus of security has become problematic. Whereas the state used to be its uncontested site, a number of scholars now treat the individual as the primary site of security-so-called 'human' security-only to be outflanked by advocates of 'international' or even 'global' security. Finally, there has been a shift in orientation: instead of defining security studies in terms of a 'referent object,' many scholars now approach security as a 'technique of government.' Drawing on Foucault's work, they have stepped away from examining practices of sovereignty, and moved towards practices of discipline and, most importantly, towards practices of 'governmentality,' with a view to analyzing and critiquing how 'security professionals' construct discrete fields of insecurity. But unless this reorientation comes to terms with the concept of security, its reference to certain practices as security practices remains thoroughly arbitrary. In short, security studies is in a state of considerable disarray as concerns its object of study. ${ }^{3}$

The quandary confronting contemporary security studies, their valuable insights notwithstanding, provides a prima facie justification for adopting a different approach to security. The approach I favor focuses on what remains more or less implicit and taken for granted when security scholars attempt to define their object

\footnotetext{
1 Notable contributions include Huysmans (2006), Anderson \& Apap (2002) and Bigo (1996).

${ }^{2}$ Huysmans (1996, pp. 15-45) offers a comprehensive analysis of the debate internal to security studies on the meaning of security.

3 Loader and Walker (2007) is a cogent and wide-ranging inquiry into the concept of security motivated by a similar dissatisfaction with the treatment of security in contemporary security studies. But whereas they are concerned to outline the instrumental, social, and constitutive dimensions of security as a 'public good,' my inquiry focuses primarily on the third of these dimensions. In particular, I seek to establish why and how publicness - understood as commonality-is itself most fundamentally at stake in collective (in)security.
} 
of study: the problem of (dis)order. In effect, the 'securitization' of immigration, as critical security scholars put it, is a specific response to the perception of border crossings by aliens as a disruption or disturbance of political order. Whereas insecurity is intimately connected to the experience of disorder, security is linked to acts of ordering, of instituting order in response to what disrupts it. To the extent that they disrupt political order by disturbing the distinction between inside and outside, border crossings by immigrants attest ex negativo to the general function of order: to 'limit the unlimited, to determine the relatively indeterminate' (Cassirer 1985 , p. 100). There can be no order without boundaries of some sort that separate and unite the elements that compose it, which means that to order is, first and foremost, to posit boundaries-Grenzsetzung, in Cassirer's words. The intuition guiding the forthcoming inquiry is, therefore, that insecurity is intimately linked to those events in which boundaries are challenged, and security to the responses through which boundaries are posited anew.

\section{Collective Self-Legislation}

To be sure, this is but a preliminary and crude approximation of the relation between (in)security and political order. To get a handle on this difficult relation, I will introduce two assumptions that also circumscribe what would otherwise be too vast a field of inquiry for the purpose of this paper. The first is that the ordering of political community is, in modernity, a collective self-ordering. Modernity views the ordering of political community as a reflexive process, in the specific sense of the term that I will outline shortly. The second is that while law certainly doesn't exhaust the concept of political community, legislation-collective self-legislation-is a privileged (but by no means the only) medium by which modern political communities order themselves. Let us begin, then, by considering why collective self-legislation is a form of collective self-ordering, and why it instantiates the general achievement of order-to limit the unlimited.

By asserting that legislation is an act of collective self-legislation I am claiming that legislative acts are acts in the first person plural perspective of a 'we.' Indeed, contemporary studies in collective intentionality and action give the lie to theories of social action that view the self of collective self-legislation as a summation of individual acts, while at the same time steering clear of an ontology that postulates that collectives exist independently of individuals and their acts (Bratman 1999). Accordingly, collective self-legislation is a species of collective action; it denotes those acts whereby the members of a polity are deemed (1) to articulate a common interest by referring to themselves as the collective that (2) enacts legal norms and (3) for the sake of which those norms are enacted. ${ }^{4}$

Having outlined in what sense legislation is an act of collective self-ordering, let us now look at how legislation is an act of collective self-ordering, that is, the different ways in which legal norms regulate human behavior. The basic idea, which

\footnotetext{
${ }^{4}$ A more fine-grained version of this reading of collective self-legislation can be found in Van Roermund (2003).
} 
the legal doctrine captures in terms of the subjective, material, temporal, and spatial 'spheres of validity' of legal norms, is that the law orders human behavior by determining, explicitly or implicitly, individually or in general, who ought to do what, when, and where. To the extent that each of these four ways of ordering behavior is part and parcel of a single process of collective self-legislation or selfordering, the who, what, where, and when of legislation are both subject-relative and relative to a common interest or purpose. Let us briefly examine how these forms of relatedness play a role in the fourfold ordering of human behavior.

The material and subjective spheres of validity of legal norms are subject-relative because the members of a polity view themselves as the collective that ascribes rights and obligations to individuals, and for the sake of whom those acts settle what rights and obligations accrue to whom. Moreover, collective self-legislation also entails that the subjective and material spheres of validity of legal orders are necessarily bounded. The key here is the reference to a common interest. Indeed, a common interest is always determinate: some interests are selected as worthy of legal protection and others discarded, usually implicitly, as legally irrelevant. That the material sphere of validity of legal norms and orders is bounded means, therefore, that only a finite range of rights and obligations is made available by any given legal order, because these rights and obligations give legal content to a bounded common interest. The same holds for the subjective sphere of validity of a legal order, beginning with membership in a collective. In effect, there could be no membership in the absence of a shared interest that allows of determining who is a party thereto and who, by implication, can ultimately be deprived thereof, in case s/ he radically contests the commonality of that interest.

If the subjective and material spheres of validity of legislation are reflexively structured and thereby bounded, so also is legal temporality. At one level, the law relies on calendar time, as when visas establish the period during which an alien may sojourn in a polity. But legal time is never only calendar time; the time of the law is first and foremost a subject-relative form of temporality, namely the historical time of a collective. As legal norms are posited from the first person plural perspective of a 'we,' they situate human behavior in the temporal arc spanning past, present, and future. These temporal modes appear as a unity to the extent that the members of a community attribute them to themselves as their past, present, and future. Moreover, the reflexive constitution of legal time is linked to the commonality of historical time, in the twofold sense of a time that is shared by and distinguishes the members of a collective. In this fundamental sense legal time is a bounded time; it conditions the use of calendar time to set temporal limits to human action, such as in visas that establish initial and final dates of sojourn for foreigners.

Finally, also legal space is reflexively structured and, consequently, necessarily bounded. That legal space is subject-relative means, in line with collective selflegislation, that it arises through self-closure: a group of individuals view themselves as the collective that posits the boundaries of legal space and for the sake of whom those boundaries are posited. Moreover, the reflexivity of legal space is intimately linked to the claim that it is the common space of a collective, a distribution of places that lends spatial form to what is held to be 
the common interest of a community. For example, the common space of a polity can be organized in terms of the distinction between public and private places. In virtue of their mutual implication and differentiation, private and public places are locations within a more encompassing spatial unity. Moreover, the way in which the law differentiates these two kinds of places depends on what a polity deems to be the common interest. In this vein, the interpretation of the common interest in a socialist polity clearly leads to a very different differentiation of public and private places than in a capitalist polity. Crucially, the commonality claimed for a legal space also explains why any conceivable polity is necessarily bounded in space. For the claim that a space is common can be contested by boundary crossings that, in the name of a conflicting interpretation of the common interest, call into question the commonality, hence the unity, of a legal space. These boundary crossings intimate an outside in the strong sense of a place that has no place in the unity of places made available by a legal space. ${ }^{5}$

In short, collective self-legislation denotes acts in which a collective orders itself by determining in its own interest who ought to do what, where, and when. To 'determine' means, for each of these spheres, to include and (implicitly) to exclude, i.e. to 'limit the unlimited' (Cassirer). Indeed, collective self-legislation denotes legislative acts whereby, acting in its own interest, a collective limits (1) who ought to be a member of a polity and, more generally, who ought to be a recipient of rights and obligations, (2) what rights and obligations are available in the legal order, (3) which distribution of places determines a legal space as the common space of the collective, and (4) what shared understanding of past, present, and future enables the members of a collective to view themselves as engaging in an ongoing collective project. Crucially, there is an internal correlation between collective selfhood and the four kinds of boundaries of legal order: as collective selfhood involves a manifold of individuals that refer to themselves as a unity in legislative action, these individuals identify themselves as a unity by way of the fourfold boundaries of legal orders. Conversely, because the legal boundaries of a polity have a reflexive structure, they enable a manifold of individuals to view themselves as a 'we', that stands in contrast to 'others'. In short, the master distinction between collective selfhood and alterity acquires institutional form through the fourfold boundaries of legal orders.

If we now return to the AFSJ, we can see why collective self-legislation is the basic format of the treaties of the European Community and the European Union. Notice, firstly, the reflexive structure that defines the treaties as acts of collective self-ordering: 'By this Treaty, the High Contracting Parties establish among themselves a European Community ...' (Art. 1 ECT, emphasis added). The phrasing of Art. 1 TEU is well-nigh identical: 'By this treaty, the High Contracting Parties establish among themselves a European Union, hereinafter called "the Union", This reflexive formulation reappears in Article 2 TEU: 'The Union shall set itself the following objectives: ...-to maintain and develop the Union as an area of freedom, security and justice' (emphasis

\footnotetext{
$\overline{5}$ See Lindahl (2006) for a fuller discussion of the structure and genesis of legal space.
} 
added). ${ }^{6}$ If Articles 1 and 2 TEU are merged together and formulated in the first person plural form, they read as follows: 'By this Treaty, we, the High Contracting Parties, agree to establish, maintain and develop among ourselves an area of freedom, security and justice'. Importantly, the reflexivity of collective self-legislation encompasses both the supranational components of European law, under the EC, and the intergovernmental components thereof, under the EU. In effect, the concept of collective self-legislation is sufficiently capacious to accommodate polities that have individuals as their immediate members and interested parties, or as their mediate members and interested parties, as is the case in international treaties by states. For, to recall the definition outlined hitherto, collective self-legislation amounts to legislative acts by which the members of a polity are deemed to (1) articulate a common interest by referring to themselves as the collective that (2) enacts legal norms and (3) for the sake of which those norms are enacted. This is not to deny, of course, that there are significant differences between the supranational and intergovernmental features of European law, and that these differences have a bearing on the AFSJ, which straddles both the EC and the EU. But as the forthcoming analysis is primarily concerned with exploring how freedom, security, and justice are linked to the general structure of political reflexivity, I will use hereafter the generic expression 'European polity.'

We should also note that the Treaties are acts of collective self-ordering because they posit the boundaries of the European polity in the four senses noted above. In effect, the contracting parties determine among themselves, at least initially, who is a party to the collective, by including Europeans; what is their common interest, by including therein interests such as the 'harmonious and balanced development of economic activities' and a 'high level of employment and of social protection' (Art. 2 ECT); where this interest is located, by including Europe as an internal market within the global market; and when the common interest comes about, by including a European history within a more encompassing world history viewed as the ongoing process of realizing a market. Notice, finally, that the treaties do not-and need not-explicitly state what has been excluded from the European polity in each of these fourfold senses; this is established retroactively, when authorities determine whether what calls for legal qualification falls within the fourfold scope of the European legal order.

These considerations, however briefly sketched, explain the ways in which immigration policy is part and parcel of the ongoing process in which the European

\footnotetext{
${ }^{6}$ To be sure, whereas Art. 1 TEU contains a reference to 'the Union', there is no parallel evocation of 'the Community' in Art. 1 ECT. Yet this difference is purely nominal from the perspective of reflexivity: in both cases, a manifold of parties establish a collective between themselves in their own interest. A comparable, purely nominal difference is visible in Articles 2 ECT and 2 TEU. Whereas the former refers to the Community's 'tasks', the latter refers to the Union as 'setting itself' a number of objectives. Nothing would have changed, legally or politically, if Article 2 ECT had stated that the Community 'sets itself' certain tasks. As is the case for Article 3 TEU, such a formulation would merely mean that the Community's Member States announce their intention to legislate jointly and in their joint interest in the fields indicated therein.
} 
polity orders itself by positing the four kinds of legal boundaries that regulate human behavior. ${ }^{7}$

\section{Illegality and Alegality}

I claimed at the outset of the previous section that there is an intimate link between order and security, on the one hand, and disorder and insecurity, on the other. Having sketched out the main features of collective self-legislation, defined as an act of political self-ordering, I will now introduce the notion of legal disorder, thereby clearing the way for a discussion of the concept of insecurity in the following section. The main thrust of this section is to identify and analyse two distinct albeit related manifestations of legal disorder, which I will call illegal and alegal acts.

At one level, of course, the distinction between legal order and disorder amounts to the distinction between, respectively, legal and illegal acts. On this reading, legal disorder ensues when human behavior breaches a legal norm, that is, when it breaches any of the four kinds of boundaries instituted by a legal order. There is, however, a second form of legal disorder, which is linked to a problem I deliberately passed over in silence when analyzing the basic features of legal order, as captured in collective self-legislation. In effect, my account there took for granted that the fourfold Grenzsetzung that gives rise to a collective has already taken place, such that acts of positing its boundaries merely reposit these. But this assumption conceals the fact that, by definition, acts that create legal orders cannot themselves be a part thereof. ${ }^{8}$

The key recital of the Preamble to the Treaty of Rome neatly illustrates this paradox: 'determined to lay the foundations of an ever closer union among the peoples of Europe.' The recital not only posits unity as the future vanishing point of the integrative process but also claims that there already was a union at the time of laying its legal foundation in the Treaty of Rome, a community of peoples who, by virtue of their shared interests, can go further together, engaging in a process of legal and economic integration. So, the wording of the recital implies that the Treaty of Rome builds on a prior limitation of the who, what, where, and when of political community, merely providing this bounded community with an institutional setting and specific goals. But to accept that the Treaty does no more than reposit boundaries would be to forget that while the six founding Member States claimed to represent European unity, they had received no legal mandate to this effect from all possibly affected parties, whether states or individuals, nor could they have, because the Treaty provides an initial delimitation of who is an affected party. By taking the initiative of founding the European polity, the signatories seize Europe: they posit

\footnotetext{
7 Arguably, UN-legislation can be construed as falling under the concept of collective self-legislation. But as UN-legislation is not enacted with the direct participation of individuals as 'citizens' of the UN, it lacks the full-blown political significance associated with collective self-legislation in polities such as nation-states or the European polity. A further development of the concept of collective self-legislation, which falls beyond the scope of this paper, would engage with theories of legal order in general, and with Hart's notion of the 'internal perspective' in particular.

8 See Van Roermund (1997).
} 
$a b$ initio the who, what, where, and when of the European legal order. This paradox reappears, unabated, in the circularity that governs European immigration policy: while the European polity claims a right to inclusion and exclusion for itself because Europe is the place of its citizens, a seizure gives rise to Europe and to European citizens, to begin with. ${ }^{9}$

This paradox is crucial for our purposes because it points to a second form of disorder. Indeed, the founding acts of legal order are themselves neither legal nor illegal because both terms of this binary distinction already presuppose a legal order as the condition for their intelligibility. Instead, foundational acts are alegal because they institute the distinction itself between legality and illegality. Only retrospectively, if they catch on, can they come to manifest themselves, albeit precariously and incompletely, as legal acts. To the extent that such acts posit the fourfold boundaries that determine a political community, each of these ways of drawing the distinction between legality and illegality exhibits a form of alegality. Indeed, those who institute the distinction between member and non-member are acivic, for they are neither members nor non-members; the acts that identify which rights are available in a legal order are anomic, for they are not themselves the exercise of a right or competence, or in breach thereof; the closures that distinguish inside from outside are atopic, by dint of being neither inside nor outside a polity; and the acts that project and retroject the historical time of a collective are achronic, for they give rise to the temporal arc spanning the past, present, and future of a collective.

These considerations have a direct bearing on collective self-legislation. The alegality of foundational acts implies that these acts, by dint of positing the fourfold boundaries of a legal order, do not fall on either side of the master distinction between selfhood and alterity; on the contrary, they are acts that introduce the cleavage in the very process of claiming to represent a collective. If the individuals whom such acts invoke as members of a group attribute these to themselves as their own acts, the distinction between selfhood and alterity takes hold, albeit incompletely and provisionally, such that alegal acts appear retrospectively as having been legal, as acts of collective self-legislation.

Accordingly, the conditions that govern the inception of a legal order also call forth disorder, during that order's later career, in the form of behavior that is not only illegal but also alegal. I mean by this behavior that contests the fourfold distinction between legality and illegality, as drawn by the legal order, intimating another way of distinguishing between these terms. Alegal acts expose the gap between actual and possible law; they not only break the law but also transgress it. Importantly, the ' $a$ ' of alegality doesn't mean the other of legality, for if such were the case then alegal acts could never manifest themselves as such to a legal order. Instead, it means that such acts disrupt a legal order by revealing another legality, other possibilities of drawing the distinction between legality and illegality in the legal order they contest. More precisely, alegal acts contest a legal order by intimating a possible legality of illegality, and a possible illegality of legality.

The notion of 'economic' immigrants, which has gained widespread currency in the debate about European immigration policy, illustrates this point.

\footnotetext{
9 See Lindahl (2004).
} 
Authorities continuously point to the fact that the former take advantage of and abuse political asylum laws to gain entry into the European polity, only to disappear into clandestine and illegal participation in the common market. Yet, to the extent that the Treaty of Rome not only separates an internal market from an external market, but also includes both in a global market, the Treaty indirectly acknowledges that all participants in the global market have an interest in the European polity positing the legal boundary between the internal and external markets in a way that preserves the commonality of the global market. ${ }^{10}$ The entry into the European polity of economic immigrants from poor countries can be seen as intimating that the polity regulates and promotes the internal market vis-à-vis the external market in a manner that doesn't safeguard the commonality of the global market in which it claims to take up its place. By holding the European polity to its claim that the realization of the internal market is part and parcel of the realization of a common global market, the border crossings of economic immigrants from poor countries are alegal: they intimate a possible legality of what becomes illegal participation in the internal market and the possible illegality of the legal acts by which the European polity has posited the normative distinction between the internal and external markets.

Immigration, on this reading, has the potential to disorder the law by contesting the commonality claimed for a legal order. In the same way that the act that posits the spatial borders of a polity can never be entirely brought under the aegis of the law, challenges to those borders resist, to a lesser or greater extent, legal qualification in terms of the jus includendi et excludendi a political community claims for itself. More generally, what renders immigration eminently disorderly is its capacity to transgress, at one stroke, the four kinds of boundaries that determine legal order, and therewith the distinction between collective selfhood and alterity, by questioning the legal determination of citizenship, the rights made available by the law, the commonality of legal space, and the normative sense of the ongoing project that holds together a collective history as the unity of its past, present, and future.

The strong form of disorder provoked by alegal acts casts new light on Cassirer's characterization of order. To the extent that the basic achievement of legal order is to limit the unlimited, exclusion has a positive significance, for without it no legal order would be possible; but this achievement is irreducibly ambiguous, for exclusiveness also ensures that no legal order ever succeeds in consolidating itself fully. Although there can be no political community unless member can be distinguished from non-member, rights from legally irrelevant claims, inside from outside, and a collective history from times that are beyond time, no legal order ever fully succeeds in bringing these distinctions themselves into the fold of legality. In a word, legal orders are irredeemably contingent. ${ }^{11}$

\footnotetext{
${ }^{10}$ For a comprehensive analysis of this enlarged first person plural perspective see Lindahl (2007).

11 This analysis lies close to the concept of order espoused in Waldenfels (1996).
} 


\section{Collective Insecurity}

Having sketched out the main lines of legal order and disorder we can now turn to insecurity. In particular, we must clarify why collective selfhood plays a key role in making sense of this transition: collective insecurity, no less than legal disorder, presupposes the first person plural perspective of a 'we' as a unity in legislative action.

Let us note, to begin with, that, as far as collectives are concerned, it would be a mistake to reduce insecurity to the specific states of mind of the individuals that compose them, such as fear, unease, or terror. Although these psychological states are certainly an ingredient of collective insecurity, they do not clarify what constitutes it as a legal-political phenomenon. The political contours of collective insecurity can be clarified if we reflect on the notion of collective self-legislation. Indeed, political modernity holds that the ground of a legal order is the collective self, the group of individuals who view themselves as a unity that legislates in its own interest. To ground an act as a legal act means, accordingly, to be able to attribute it to a group of individuals as their joint author and as the group that has a joint interest therein. This is pertinent to the problem of security if we bear in mind that to secure means, amongst other things, to ground something. On this reading, collective insecurity, and the individual states of fear, unease, and even terror to which it can give rise, concerns an experience of groundlessness, of the nonattributability of certain acts to a collective.

But if groundlessness or non-attributability is its common root, the distinction between illegal and alegal acts introduces an important bifurcation in collective insecurity, even if neither of its two manifestations is ever given in its pure form. The acts by authorities that qualify human behavior as illegal effectively claim that such behavior cannot be attributed to a collective because they are in breach of legal norms deemed to have been enacted by that collective in its own interest. This is clearly the case in acts that, say, declare illegal the sojourn of an immigrant who has entered a member state of the European polity without the requisite visa. In other words, the authority claims that the members of the collective reject attributing to themselves the immigrant's stay as an act they have jointly authorized and as an act in which they have a joint interest. This means that illegal acts create a condition of collective insecurity to the extent that they imperil the capacity of a group of individuals to order interpersonal relations in the community in their mutual interest. The illegal act is groundless because it cannot be attributed to the collective that must authorize it. Accordingly, that we are a collective and what we are as a collective-as articulated in the who, what, where, and when of political community-are assumptions that remain more or less unproblematic and taken for granted in the official act that qualifies behavior as illegal. In other words, the official acts that declare acts illegal, hence non-attributable, effectively validate the master distinction between collective selfhood and alterity.

Like illegal acts, alegal acts also give rise to collective insecurity by evoking an experience of groundlessness. But the groundlessness they expose is distinct from that of illegality, even though neither of these forms is ever given in its pure form. As we saw in the previous section, there can be no legal order unless someone who 
has not and cannot have been mandated to this effect seizes the initiative, claiming to legislate on behalf of and in the interest of a collective. Legislative acts constitute us as a collective self in the very process of attributing legislation to us as a self. Accordingly, the attribution of legal norms to a group of individuals as their interested author has an ineradicable core of groundlessness to it. This residual groundlessness is precisely what legal disorder, in the form of alegal acts, brings into view. An example of such an act would be the occupation of a government building by a group of individuals who, acting under the banner 'not in our name,' protest against the deportation of illegal immigrants from a member state of the European polity. A form of alegality that is an inverted image of the occupation of a government building consists in economic immigrants who arrive from poor countries. They can also be seen as entering under the banner 'not in our name,' to the extent that the European polity regulates the internal market and its relation to the external market in a way that doesn't safeguard the common interest of those who participate in the global market. These two evocations of alegality are inverted images of each other because, whereas the 'not in our name' of the protesters rejects that legislation be attributed to them, the 'not in our name' by immigrants demands that legislation be in some way attributed to them. Hence, alegality arrests the attribution of legislation to a collective self by calling into question the group of individuals to whom legislation has been attributed as having an interest therein. Alegality suspends the attribution of legislation to a collective self because the distinction itself between collective selfhood and alterity becomes more or less indeterminate: the collective self manifests itself as other, and the other as collective self. This indeterminacy comes to the fore in cries such as 'Another Europe is possible,' which contest the claim that what renders individuals the members of a European polity is their shared commitment to the realization of a common market. Here, then, is a second form of collective insecurity: by contesting what we are as a unity, i.e. by challenging the commonality claimed for the who, what, where, and when by means of which we view ourselves as a 'we,' alegal acts also contest, to a lesser or greater extent, that we view ourselves as a 'we,' that we exist as a collective.

In short, collective insecurity manifests itself in the two forms of groundlessness to which collective self-legislation is exposed. Illegal acts are groundless in that they are not attributable to a collective as authored or authorized by it. Alegal acts contest a collective self as the ground of legislation, intimating another collective self to whom legislation should be attributed as its interested author.

Let me conclude this section by tying together the different strands of my argument about insecurity. Although, as pointed out earlier, disorder registers in a legal order as illegal acts, there is a more fundamental, albeit indirect, manifestation of legal disorder that calls into question the very distinction between legality and illegality: the alegal act. Accordingly, I want to differentiate collective insecurity in terms of primary or secondary challenges to a legal order. Primary challenges call into question the very distinction between legal and illegal acts, as posited in a legal order; secondary challenges do not. But the former notion is in need of further differentiation. If we bear in mind that alegal acts lay bare the contingency of a polity, in the sense that its legal order actualizes only one among various possible 
orderings of human behavior, then we need to distinguish between alegal acts that open up a collective to alternative legalities that fall within the circle of its own possibilities, and alegal acts that intimate possibilities beyond the polity's reach, because to embrace them would be to destroy the conditions of its own possibility. While both forms of collective insecurity are primary, the first is weak, the second, strong. In effect, the latter confronts a collective with a possibility it cannot embrace as its own without ceasing to exist as a collective-an impossible possibility. This is what a polity calls terrorism. ${ }^{12}$

\section{Collective Security}

After having successively explored legal disorder and collective insecurity we can now turn to examine collective security. To introduce this penultimate section I want to highlight an implication of the considerations above that is elementary, in the sense of irreducible, and for this reason also of the greatest consequence: (in)security is constitutive of selves, individual and collective. An inquiry into collective (in)security is at bottom an inquiry into the ontology of collective selfhood. In the strong sense of the term 'insecurity' outlined heretofore, only beings for whom questionability is their mode of being, i.e. that have to deal with the residual groundlessness concerning what they are and that they are, can be insecure. Having 'to deal' with this residual groundlessness means, for collectives, having to determine time and again, in response to what demands legal qualification, what defines them as unities, i.e. which determinations of the who, what, where, and when of political community are their own possibilities, in the light of the background possibility that they might cease to exist altogether as groups. If collective selves are constitutively insecure because they exist in the mode of a finite questionability, the possibility and the meaning of collective security resides in the fact that collective selves also exist in the mode of a finite responsiveness. This is, I submit, the 'existential' core of collective selflegislation.

Collective security, on this account, encompasses those acts by which collectives posit the boundaries of legal order in response to acts that challenge those boundaries. To the extent that these challenges are primary or secondary, two forms of collective security can be distinguished, even though neither is ever given in its pure form. The first is boundary-enforcement in response to illegal acts. This is the proper locus of security as 'law enforcement,' in the very broad sense of all

\footnotetext{
12 Notice that terrorism is a relative concept insofar as it presupposes the first person plural perspective of a 'we.' The failure of the Bush Administration to obtain worldwide consensus on an univocal definition of terrorism shows that there is no bird's eye view of what counts as terrorism, no 'universal,' subjectindependent definition thereof. Moreover, by qualifying an act as terrorist, a polity denies that this act can be the index of another legality, claiming, instead, that it is the expression of sheer illegality, hence that it is the acute manifestation of what I have called a secondary form of collective insecurity. Paradoxically, what definitively eludes the distinction between legality and illegality, as posited by a polity, is qualified as the definitive confirmation thereof, such that there is no option but to enforce the distinction, or so legal authorities claim. In this sense, terrorism is also an absolute concept.
} 
measures destined to maintain the distinction between legality and illegality, as posited in the legal order. Thus defined, it includes, in the case of European immigration policy, passport controls, visas, electronic fences, registration, work permits, risk profiles, the nascent Rapid Border Intervention Teams (RABITs), and the like. By enforcing boundaries, this mode of collective security reaffirms what we are deemed to be as a collective and that we are deemed to be a collective; in this twofold sense, law-enforcement attributes legislation to a collective self, claiming that it is the ground thereof.

The second form of collective security is boundary-constitution in response to alegal acts. In the face of a primary challenge to legal order, political judgment can claim to restore its contested commonality by redefining the fourfold distinction between the legal and the illegal. Boundary-constitution is, of course, a foundational act, an alegal response to alegal behavior: the disruption of the distinction between selfhood and alterity elicited by primary challenges to legal order is responded to by acts that posit the distinction anew from a position that is neither that of a collective self nor of its other. Crucially, boundary-constitution claims to secure legal order. For if primary challenges expose the residual groundlessness of legal order, boundary-constitution claims to restore the attributability of legislation to a collective self by redefining the who, what, where, and when of political community. For example, in response to the challenge, 'not in our name,' with which protesters contest the deportation of illegal immigrants or economic immigrants demand that their interests be taken into account, the European polity's authorities might adopt legislation lowering import tariffs on products from poor countries. In particular, while it would continue to uphold the distinction between an internal and external market, a tariff reduction would effectively acknowledge that the measures taken to defend the commonality of a European internal market must safeguard the commonality of the world market in which the European polity takes up its place. By redefining the commonality of the European polity, the authorities who enact the tariff reduction seek to gain the assent of the polity's members who cried 'not in our name', such that these would be prepared to attribute immigration policy to themselves as members of the polity. Accordingly, to reorder the legal boundaries of a polity is to claim to secure-ground-the legal order anew in a collective self. Albeit in different ways, both forms of collective security claim to restore a collective as the ground of legal order.

There is, however, no simple sequence going from secondary challenges to boundary-enforcement on the one hand, and from primary challenges to boundaryconstitution on the other. Indeed, there is an irreducible hiatus between the questionability of legal order and the responsiveness of political judgment. This hiatus has two aspects. On the one hand, what demands legal qualification precedes the law, not merely temporally but rather because human behavior never entirely fits legal expectations. Human behavior is always in at least some measure alegal because it doesn't fulfill the anticipations of legality/illegality encoded in legal norms. So-called economic immigrants are never only market denizens, as anticipated by the European polity, nor are its members ever only market citizens. This 'precedence' shows how the meaning of human behavior is never simply a political construct. This precedence explains why alegality doesn't simply collapse 
into a 'subjective' judgment about illegality. On the other hand, the responsiveness of political judgment is never merely subordinate to what calls for legal qualification, never a fixed reaction to a pre-coded stimulus. This is not only the case because political judgment can marshal a variable range of responses to what calls for legal qualification. More radically, the response establishes retroactively whether the border crossings to which a collective responds are illegal or alegal. Whether an act is alegal or illegal isn't simply an 'objective' question, such that the act's meaning is independent of the first person plural perspective whence the act is qualified. Consequently, the sequence going from question to response has its double in the inverted sequence: legal disorder becomes a secondary challenge - an illegal act—when immigration policy enforces boundaries, and a primary challenge — an alegal act—when such policy constitutes boundaries. Immigration policy is responsive in a strong sense of the term because 'that to which it responds occurs only in responding to it' (Waldenfels 1994, p. 266). ${ }^{13}$

The retroactivity of a collective's legal responses to border crossings sheds new light on what critical scholars call the 'securitization' of immigration policy. In effect, 'securitization' amounts to a form of responsiveness to border crossings that reduces a primary to a secondary challenge to legal order. This is what is at stake in the oft-noted and critiqued 'security continuum': by placing illegal immigration on a continuum with serious crime and even terrorism, authorities effectively claim that the only appropriate way of dealing with it is boundary-enforcement. ${ }^{14}$ While challenges to legal order are, qua challenges, variable combinations of threats to and possibilities of collective selfhood, the securitization of immigration policy filters out alternative legalities intimated by border crossings, viewing border crossings primarily as a threat to the normative distinction between inside and outside, and therewith to collective selfhood. 'Securitization constitutes political unity by ... placing it in an existentially hostile environment and asserting an obligation to free it from threat' (Huysmans 2006, p. 50). Accordingly, critical scholars expose what they take to be a circularity: while political authorities claim that the task of immigration policy is to enforce boundaries because border crossings are a threat to the collective self, critical scholars claim that border crossings by immigrants become a threat to the collective self because immigration policy is set the task of enforcing boundaries. To formulate this circularity in slightly different terms, whereas political authorities claim that 'we' must engage in boundary-enforcement because 'we' are a collective and in view of protecting what 'we' are as a collective, critical scholars invert the argument: what 'we' are as a collective and that we are a collective is removed from the sphere of political contestation because we engage in boundary-enforcement. This removal is exactly what they decry as the 'identity politics' at work in the 'securitization' of immigration policy. ${ }^{15}$

\footnotetext{
13 My treatment of 'precedence' and 'retroactivity' draws on what Waldenfels calls, respectively, the Vorgängigkeit of questions and the Nachträglichkeit of responsiveness.

14 See Bigo (1996). This point is reinforced if we bear in mind that, as observed in footnote 13 by qualifying an act as terrorist, authorities commit to uncompromising boundary-enforcement.

15 This strong sense of responsiveness explains why security technologies, as has often been noted, constitute insecurity in the very process of combating it. See Huysmans (2006, p. $91 \mathrm{ff})$.
} 
The critique of 'securitization' certainly has a salutary effect by unmasking the reductive move to which political authorities are prone when justifying boundaryenforcement. Yet I wonder whether this critique doesn't itself also risk falling prey to the inverted form of reductionism, to the extent that it tends to view insecurity as being by and large a political construct. The whole point of my analysis of the hiatus between question and answer is to show that there is an irreducible indeterminacy concerning the 'objective' status of an act as alegal or illegal and its 'subjective' legal qualification. What is the nature of the border crossing by an immigrant, and how it should be responded to, are issues that resist definitive resolution either way. ${ }^{16}$

If the law can only qualify human behavior in general, and border crossings by immigrants in particular, as legal or illegal, how can it at all be responsive to alegality? The solution to this problem resides in the paradox outlined in section 'Illegality and Alegality': the Treaty of Rome, as all foundational acts of political community, originates the fourfold boundaries of the European polity by repositing its original boundaries. Not only must the European polity qualify each border crossing as legal or illegal, but each of these crossings inevitably confronts the European polity with the question concerning an original unity to which it has no direct access, yet which it has to determine time and again through the legal qualification of border crossings. Accordingly, immigration policy is never only about enforcing the distinction between legal and illegal border crossings; immigration poses a policy issue, that is, it calls for political judgment by the authorities of the European polity and its Member States, because each legal qualification of a border crossing is also, and unavoidably, an assessment about what counts as a legal and an illegal border crossing. In other words, the responsiveness of immigration policy is conditioned by the fact that although legal acts can only qualify border crossings as legal or illegal, immigration policy cannot but constitute the fourfold distinction between the legal and the illegal each time around, even when it enforces how these boundaries have been drawn. In this strong, paradoxical sense, immigration policy must order political community $a b$ ovo to be able to reorder it. Returning to the question formulated at the outset of this paragraph, political judgment can respond indirectly to alegal border crossings by retroactively ordering anew the normative distinction between inside and outside and, therewith, the qualification of border crossings as legal or illegal.

\section{Security, Freedom, and Justice}

But a final, pressing problem requires our attention: although immigration policy can respond indirectly to primary challenges to legal order by engaging in boundary-constitution, why should it do so? Why not persevere unstintingly in the enforcement of boundaries in view of securing a legal order, especially because

\footnotetext{
16 The danger of reductiveness is particularly apparent in the strand of critical security studies that stresses the 'performativity' of the 'speech acts' by which certain situations are 'securitized.' The political constructivism this approach endorses is reductive because, by focusing on the retroactivity of responsiveness, it neglects the precedence of that to which security acts respond. See Waever (1995, pp. 54-57).
} 
alegal behavior only manifests itself indirectly, through what is prima facie an illegal act? This question points to the background problem concerning the general relation between security, freedom, and justice. Indeed, the European polity's authorities claim that securing the borders of the polity is instrumental to freedom and justice; that boundary-enforcement in response to illegal immigration is a manifestation of freedom and justice. Why, if at all, should they seriously consider the charge that 'securitizing' immigration policy imperils freedom and justice?

Although this paper has focused on collective self-legislation in view of understanding the 'deep structures' of collective security, collective self-legislation is the common root of security, freedom, and justice. If security concerns the acts by which the members of a collective jointly (re)order themselves in response to what disrupts their legal order, freedom denotes the self-ordering acts in which the members of a collective jointly enact legislation in their own interest, and justice the acts by which the members of a collective order interpersonal relations in their own interest by meting out to each their own. Consequently, freedom, security, and justice are internally related because they are three aspects of the single process of collective self-legislation. And to the extent that collective self-legislation involves acts by which individuals attribute legislation to themselves as members of a community, there is a strong connection between collective and individual freedom, security, and justice.

This explains, on the one hand, why the authorities of the European polity can claim that security policies enacted under the AFSJ are a manifestation of freedom and justice. To enforce the polity's boundaries in response to illegal immigration is, on the one hand, to reaffirm the boundaries that are claimed to have been jointly enacted by its members in their common interest: freedom. And to enforce boundaries in response to illegal immigration is, on the other, to distribute rights and resources among those who are deemed to be entitled thereto in conformity with the common interest: justice.

Yet, on the other hand, what alegal immigration contests is precisely the commonality claimed for the interest by reference to which a group of individuals refer to themselves as a unity in legislative action and as the unity in whose interest legislation is enacted. In other words, alegal immigration contests the boundaries that determine who belongs to the unity in legislative action and who belongs to the unity that has an interest therein. This is particularly clear in the case of so-called 'de facto immigrants,' that is, economic immigrants that use-and abuse-political asylum to make their way into the European polity. As we have seen, insofar as the Treaty of Rome and all later treaties not only separate an internal market from an external market but also include both in a global market, they indirectly acknowledge that all participants in the global market have an interest in the European polity positing the legal boundary between the internal and external markets in a way that preserves the commonality of the global market. Accordingly, the Treaty of Rome and all later legislation implicitly acknowledge that although the members of the polity have a preferential interest in the boundaries that separate the internal market from an external market, their interest therein is not exclusive. More forcefully, protecting the preferential interest of Europeans in the realization of an internal market requires that legislative acts take into account the interests of 
non-Europeans. And this entails that the first person plural perspective of 'we,' the members of the European polity, includes itself in the broader first person plural perspective of 'we,' the interested parties in the realization of a global market, as a virtual unity in legislative action. It is precisely with reference to this enlarged first person plural perspective that 'de facto immigrants' contest the boundaries that determine the European polity as a unity that legislates in its own interest: " $n o t$ in our name"-although it should somehow also be in our name'. By evoking this enlarged first person plural perspective, 'de facto immigrants' arrest the attribution of legislation to a European collective self, calling into question the group of individuals to whom legislation should be attributed because they have an interest therein. In this sense, 'de facto immigrants' intimate a residual groundlessness in European legislation. They challenge the claim that the realization of the internal market is, in the European polity's own terms, the free act of a collective which distributes to each their own. ${ }^{17}$

Returning to the question posed at the outset of this concluding section, although immigration policy can respond indirectly to this primary challenge to legal order by means of boundary-constitution, why should it? Why, if at all, should the authorities of the European polity seriously consider the charge that 'securitizing' immigration policy imperils freedom and justice?

The answer has to be that reducing primary challenges to secondary challenges ultimately compromises the conditions under which boundary-enforcement can be deemed an act of collective self-legislation. More forcefully, that primary challenges are reduced to secondary challenges becomes apparent indirectly, when boundary-enforcement is normatively compromised. ${ }^{18}$ In this roundabout manner the normative significance of border crossings by immigrants proves to be more than the mere construct of immigration policy. This problem comes to a head in what Walker dubs 'the major constitutional challenge facing the AFSJ,' namely, 'the achievement of the right balance between an effective and efficient policy capacity and output on the one hand, and an appropriate system of individual and collective accountability on the other' (Walker 2004, p. 23). This balance has become strained to the extent that boundary-enforcement by 'security professionals' increasingly circumvents or is placed beyond the pale of accountability mechanisms in the effort to fend off illegal immigration. In these situations, the 'effectiveness' and 'efficiency' of immigration policy boils down to its naked factuality, a de facto response to de facto immigration. Insofar as accountability mechanisms are a means

\footnotetext{
17 That a form of economic immigration might pose a primary challenge to the European legal order should not be surprising. As the Treaty of Rome and all further primary and secondary legislation determine the common interest of the European polity largely in terms of the realization of a common market, contestation of the boundaries of the polity is, to borrow from Hegel, a form of 'determinate negation.' But Hegel's insight is only half of the story, for the inversion of question and response referred to earlier is once again at play. Indeed, the kind of question or challenge that immigration poses to the European polity is determined in advance, even if never completely, by the kind of response the polity can offer to boundary crossings. The qualification of border crossings as economic immigration both subverts and consolidates the European polity, both opens up and closes down the meaning of border crossings into the polity.

${ }^{18}$ For this reason, the concept of security cannot be limited to boundary-enforcement, in the broad sense noted above; it also always includes boundary-constitution.
} 
to determine when an act can be earmarked as legal, and therewith attributed to the members of a polity as its joint authors, these situations mark the point at which boundary-enforcement becomes groundless, that is, when boundary-enforcement ceases to be an act of collective self-legislation: the free act of a collective that metes out to each their own.

Acknowledgments I appreciate helpful remarks on a preliminary version of this paper by Luigi Corrias, Ivana Ivkovic, David Janssens, and Nanda Oudejans. This paper was written with the financial support of the Netherlands Organisation for Scientific Research (NWO).

Open Access This article is distributed under the terms of the Creative Commons Attribution Noncommercial License which permits any noncommercial use, distribution, and reproduction in any medium, provided the original author(s) and source are credited.

\section{References}

Anderson, Malcom, and Joanna Apap Apap. 2002. Striking a balance between freedom, security and justice in an enlarged European Union. Brussels: Centre for European Policy Studies.

Bigo, Didier. 1996. Les polices en réseaux. Paris: Presses de la Fondation Nationale des Sciences Politiques.

Bratman, Michael. 1999. Faces of intention. Cambridge: Cambridge University Press.

Cassirer, Ernst. 1985. Symbol, Technik, Sprache : Aufsätze aus den Jahren 1927-1933. In eds. Ernst Wolfgang Orth \& John Michael Krois. Hamburg: Felix Meiner Verlag.

Huysmans, Jef. 2006. The politics of insecurity: Fear, migration and asylum in the EU. London: Routledge.

Lindahl, Hans. 2004. Inside and outside the EU's 'area of freedom, security and justice': Reflexive identity and the unity of legal space. Archiv für Rechts- und Sozialphilosophie 90: 478-497.

Lindahl, Hans. 2006. Give and take: Arendt and the nomos of political community. Philosophy and Social Criticism 32: 881-901.

Lindahl, Hans. 2007. Breaking promises to keep them: Immigration and the boundaries of distributive justice. LSE Law, Society and Economy Working Papers 3/2007: http://www.lse.ac.uk/collections/ law/wps/WPS03-2007Lindahl.pdf (accessed 10 July, 2008).

Loader, Ian, and Neil Walker. 2007. Civilizing security. Oxford: Oxford University Press.

Van Roermund, Bert. 1997. Law, narrative and reality: An essay in intercepting politics. Dordrecht: Kluwer Academic Publishers.

Van Roermund, Bert. 2003. First-person plural legislature: political reflexivity and representation. Philosophical Explorations 6: 235-252.

Waever, Ole. 1995. Securitization and desecuritization. In On security, ed. Ronnie D. Lipschutz, 46-86. New York: Columbia University Press.

Waldenfels, Bernhard. 1994. Antwortregister. Frankfurt: Suhrkamp.

Waldenfels, Bernhard. 1996. Order in the twilight [1987] (trans. Parent D.J.). Athens, OH: Ohio University Press.

Walker, Neil. 2004. In search of the area of freedom, security and justice: A constitutional odyssey. In Europe's area of freedom, security and justice, ed. Neil Walker, 3-40. Oxford: Oxford University Press. 